\title{
From Emergency Remote Teaching to Strategically Embracing Online Learning
}

\author{
Dionisia Tzavara
}

As a response to the Covid-19 pandemic, universities across the globe closed campuses, cancelled face-to-face classes, and resorted to digital instruction in an attempt to continue offering instruction, providing continuity to their students, and keeping the academic year going. This movement away from face-to-face instruction happened on a large scale (according to a World Economic Forum article "Some 1.5 billion students-close to $90 \%$ of all primary, secondary and tertiary learners in the world-are no longer able to physically go to school" (Kandri 2020), across various institutions and departments, and large numbers of students and academics were impacted by this shift to online instruction. Many termed this shift to digital instruction, "online learning", and questions were asked as to whether this was going to transform education forever in what was characterized as an unprecedented movement to online education.

Universities adapted quickly and creatively. We should commend all parties involved who, under the circumstances, did the best they could. Academics had to learn how to use various technologies, put their lectures online, create content for their students, and keep their students engaged. Students had to adapt to this new way of instructional delivery, and universities quickly came up with resources to support both students and academics. However, we need to accept that universities, students, and academics were not planning for this move from face-to-face to digital instruction. They were certainly not prepared for it. Many students are dissatisfied with this emergency unplanned shift to digital instruction. Often noting that the quality of the learning experience was not what they had signed up for and that the learning experience was inferior to what they were getting on campus, with some asking for refunds or not planning to start university next year (Moules 2020; Batty and Hall 2020). Also, many academics had no experience in digital or online teaching. Without time

D. Tzavara $(\varangle)$

University of Liverpool, Liverpool, UK

e-mail: dtzavara@gmail.com 
for training, many felt overwhelmed by the effort required and the adjustment they had to make.

Online education is not a new idea; it has been around for about three decades. There is ample research on online learning pedagogies and models, as well as the factors that determine the effectiveness of online learning. An increasing number of universities worldwide offer online education, ranging from open courses (MOOCS) and microcredentials to full degree programmes, both undergraduate and postgraduate. However, what happened this spring was not online learning, despite many referring to this shift to digital instruction as such. What happened can best be described by the term 'emergency remote teaching' which, according to Hodges et al. 2020, is "a temporary shift of instructional delivery to an alternate delivery model due to crisis circumstances. It involves the use of fully remote teaching solutions for instruction or education that would otherwise be delivered face-to-face or as blended or hybrid courses and that will return to that format once the crisis is or emergency has abated".

Online learning is not about replicating the campus learning experience or about 'translating' it to a digitally mediated format. What defines online learning is not the technology, but the pedagogy and the learning design behind it. Pedagogy must be a priority when designing online learning (Ferrel et al. 2018). Online learning, just like campus learning, requires the development of an engaged learning community. Students and educators are actively engaged to create a meaningful learning experience. Meaning that online learning is not about delivering a lecture in a digitally mediated format or about putting together lists of resources that students can access online, but rather about making sense of learning by being integrated into a community with learning as a shared goal. The role of the educator is to design the learning experience and to act as the facilitator of learning, and there is integration between the educator and the learning resources rather than the educator delivering content to students (Bower 2019).

Those of us who have been involved in online learning for years know that online learning requires careful planning and considerable expertise and that it takes months of careful planning to design and develop an online course. Learning design is very important. There are various models and theories that may be appropriate to meet the needs of different learning environments. Similarly, different technologies and learning activities will support different pedagogic approaches and objectives (Ferrel et al. 2016). Several practices that may work on campus, like delivering 2-hour lectures, will not work online. Successful online learning needs to be supported by content, resources, activities, teacher engagement and facilitation, and assessments appropriate for an online learning environment (Bower 2019). Online learning uses combinations of resources and activities to engage learners such as text-based resources, video and audio material, podcasts, blogs, learning journals, quizzes and self-assessment exercises, asynchronous discussion forums, webinars, question and answer sessions, group work, etc.

Many universities offering online learning before Covid-19 were looking to expand their online learning portfolio, either through offering more online programmes and/or credentials (e.g. microcredentials, certificates, diplomas, profes- 
sional development programmes, etc.) or by boosting enrolments through new markets. Several universities were also looking to embrace online learning by launching their first online programmes pre-Covid-19. The anticipated drop in enrolmentsmainly international enrolments - and major loss in revenues that universities face, as well as the uncertainty surrounding campus reopening, has made the need for strategic planning even more pressing. In addition to embracing online education faster and to a larger extent than planned, universities may need to continue remote instruction for longer - at least for the next academic year-due to the changing conditions that Covid-19 is creating, like social distancing.

If universities are going to accelerate their efforts to conquer online education, then a strategic approach informed by the principles of online learning design will have to be adopted. Also, if campuses are going to remain closed in the autumn, then it will not be sufficient to replicate the spring emergency remote teaching experience. Universities will have to come up with a better plan to keep students and academics satisfied and engaged. This shift to emergency remote teaching could lead not just to a boost of online learning, but also to more integration of digital technologies and technology-enabled learning in traditional campus delivery. Universities can create digital content and resources that can be used to supplement classroom instruction and make more effective use of technologies to transform the learning experience for campus students.

Now that the emergency phase of this massive digitalization has passed and stakeholders have started evaluating the experience and discussing lessons learned, universities need to come up with an online learning plan that integrates the overall strategy of the institution and is aligned with its mission. Universities will have to base their plans on the desired outcomes, the purpose of online education, and pedagogies rather than an urgent response to a crisis. Technology mediated learning can take various forms, from fully online learning to various models of blended learning, to campus face-to-face learning supported by digital technologies. Therefore, universities must understand where they want to position themselves on this spectrum. It is very easy to call all forms of technology-mediated learning online learning, but the only thing that can be achieved this way is confusion, misunderstanding, and scepticism toward online learning. At the heart of any online learning plan, we must see online learning pedagogies and theories of instructional design, as well as learning models aligned with learning objectives and learners' needs.

Academics struggled through this urgent digitalization of teaching. Several universities across the globe offer programmes which are fully online and have many faculty members with extensive experience as online academics. But the truth is that the majority of the academic community worldwide had no prior experience with technology-mediated learning, and they had no training in using digital technologies for teaching. More importantly, they lacked experience in the pedagogies of online learning and the principles of online learning design. During this period, some academics pleasantly discovered the potential that digital technology offers to educators and learners, but many were sceptical, overwhelmed, and even questioned the effectiveness of online learning and its potential to offer a fulfilling and worthwhile learning experience. Universities need to establish training programmes to support 
academic faculty in a technology-mediated learning environment, that engages them in this new learning experience while inviting them to rethink and re-evaluate their teaching practices and the ways that they interact with and support their students.

Enabling digitalization was on the agenda of higher education institutions before Covid-19, as demonstrated in the IAU Global Report on Higher Education in the Digital Era (Jensen 2019). But the experience with emergency remote teaching this spring will probably bring about a shift to the agenda for digitalization and in many cases an acceleration of plans. Given the urgency of the situation, video conferencing was probably the best that could happen in many cases. But video conferencing is not online learning, and it is not the only means to enable digitally-mediated learning. There is a richness of tools and mediums that can be used, and universities need to invest in learning technologies and management systems that will enable students with an integrated learning experience. Campus learning is not just about delivering a lecture but rather about creating an environment that integrates various elements. Including, for example, office hours, peer interaction in the department common room, seminar series, access to study skills resources, etc. Those of us who are familiar with online learning know that online learning is the same. Creating a virtual campus for learners and educators is very important, as are supporting resources for students as well as faculty. Resources will have to cover things like instructional design support, media production, technical support, student services, study skills support, library support, etc. An online learning experience must incorporate all of this, in addition to content and instructional delivery.

Many predict that this will be a turning point for higher education and that universities not embracing change will be left behind (El-Azar and Nelson 2020). Whether this is a turning point or not, it is certainly an opportunity for online learning to increase its reach in higher education, as well as an opportunity for campus education to become innovative, flexible, and adaptable. There is ample evidence to suggest that despite the criticism toward online education and the concerns that some raised about the quality and effectiveness of online education, online learning is at least as effective as traditional campus learning and can act as a facilitator of learning (Means et al. 2009; Nguyen 2015; Wilcox et al. 2016). We used to consider students of online learning programmes as non-traditional students (part-time students, with full or part-time employment and considerable professional experience in their field, mature), but given the situation with Covid-19, online learning will be the most preferred option for many traditional university students who might otherwise choose to go to campus. This is a great opportunity for online and campus education to work together with the potential to create synergies to provide innovative, current, and relevant high-quality education. 


\section{References}

Batty, D., \& Hall, R. (2020). No campus lectures and shut students bars: UK universities’ £1bn struggle to move online. The Guardian. Retrieved from: www.theguardian.com/education/ 2020/apr/25/degrees-of-separation-can-universities-adapt-in-the-rush-to-online-learning? CMP=Share_iOSApp_Other (29.04.2020).

Bower, M. (2019). Technology-mediated learning theory. British Journal of Educational Technology, 50(3), 1035-1048.

El-Azar, D., \& Nelson, B. (2020). How will higher education be different in 2030? British Council. Retrieved from: www.britishcouncil.org/voices-magazine/future-higher-education (30.05.2020).

Ferrel, G. Smith, R. \& Archer, W. (2016). Curriculum design and support for online learning. London: JISC. Retrieved from: www.jisc.ac.uk/full-guide/curriculum-design-and-support-foronline-learning (15.05.2020).

Ferrel, G., Smith, R., \& Knight, S. (2018). Designing learning and assessment in a digital age. London: JISC. Retrieved from: www.jisc.ac.uk/full-guide/designing-learning-and-assessmentin-a-digital-age. (15.05.2020).

Hodges, C., Moore, S., Lockee, B., Trust, T. \& Bond, A. (2020). The difference between emergency remote teaching and online learning. Educase Review. Retrieved from: https://er.educause. edu/articles/2020/3/the-difference-between-emergency-remote-teaching-and-online-learning. (5.04.2020).

Jensen, T. (2019). Higher Education in the digital era. The current state of transformation around the world. International Association of Universities. Retrieved from: www.iau-aiu.net/IMG/pdf/ technology_report_2019.pdf. (8.05.2020).

Kandri S.E. (2020). How Covid-19 is driving a long-overdue revolution in education. World Economic Forum. Retrieved from: www.weforum.org/agenda/2020/05/how-covid-19-is-sparkinga-revolution-in-higher-education/. (16.05.2020).

Means, B., Toyama, Y., Murphy, R., Bakia, M. \& Jones, K. (2009). Evaluation of evidence-based practices in online learning: A meta-analysis and review of online learning studies. US Department of Education. Retrieved from: https://files.eric.ed.gov/fulltext/ED505824.pdf. (28.04.2020).

Moules, J. (2020). Coronavirus pandemic accelerates shift in MBA market. Financial Times. Retrieved from: www.ft.com/content/f2d91aca-8933-11ea-9dcb-fe6871f4145a. (26.05.2020).

Nguyen, T. (2015). The effectiveness of online learning: Beyond no significant difference and future horizons. MERLOT Journal of Online Learning and Teaching, 11(2), 309-319.

Wilcox, K.E., Sarma, S. \& Lippel, P.H. (2016) Online education: A catalyst for higher education reforms. Massachusetts Institute of Technology. Retrieved from: https://oepi.mit.edu/files/2016/ 09/MIT-Online-Education-Policy-Initiative-April-2016.pdf (26.05.2020).

Dionisia Tzavara is currently the Director of Online Studies for Laureate Online Education of the University of Liverpool Online Professional Doctorates (DBA \& EdD). She has a long career in higher education, more than 14 years of experience with online learning, and she has served in various academic and managerial roles. She has been involved in the design and development of online programmes and modules. She is an active researcher with publications in academic journals and presentations at academic conferences. 
Open Access This chapter is licensed under the terms of the Creative Commons Attribution 4.0 International License (http://creativecommons.org/licenses/by/4.0/), which permits use, sharing, adaptation, distribution and reproduction in any medium or format, as long as you give appropriate credit to the original author(s) and the source, provide a link to the Creative Commons license and indicate if changes were made.

The images or other third party material in this chapter are included in the chapter's Creative Commons license, unless indicated otherwise in a credit line to the material. If material is not included in the chapter's Creative Commons license and your intended use is not permitted by statutory regulation or exceeds the permitted use, you will need to obtain permission directly from the copyright holder. 